\title{
Impact of Gender, Age and Management Style on the Success of Family Business in Kosovo
}

\author{
Rifat Hoxha ${ }^{1}$ and Hamdi Hoti ${ }^{2}$
}

\begin{abstract}
Family business is the most contributing category in the economic development of all countries. Both Developed and Developing Countries and Less Developed Family Business plays an important role in reducing unemployment and is a catalyst for developing creative ideas and innovations in all business activities. In this paper we will address some of the characteristics of managers of this business category, such as their gender, age, and style of management, and their impact on the development and growth of these businesses' performance. The paper is part of the survey conducted by the survey of over 300 family businesses in Kosovo and was used by the author for the preparation of doctoral dissertation. This paper is fulfill from the survey which is realized with professors of Economic field in University of Prizren "Ukshin HOTI" in Prizren. From those finding results of research we give some modest recommendations and it's more raising awareness especially business management from female gender as an opportunity to duplicate the potential for a development and performance of those business. This is based on the fact that the more thought we have, the more ideas come about how we can manage a family business with contemporary style, without a gender or age complex, which can guarantee success not only in our country, but to become competitive and penetrate the markets of the most developed countries.
\end{abstract}

Keywords: Family business, Gender, Age, Management style

\section{Obstacles in Increasing of Family Business}

Knowing that Kosovo is still a developing country and is moving very slowly towards economic development, family businesses in Kosovo have many obstacles to their growth and development. Different scholars identify different obstacles in the development of family businesses. The main obstacles to family business development are: Innovation, Export and Trade, Strategy, Planning and Management (Doern, 2009). Other authors have split BF growth barriers into two major classifications that depend on internal factors such as: owner restrictions and business size, as well as external factors such as Industry and Competition. Seeing that family businesses may face insecure barriers with their forces, domestic institutions should support this business category so that the country has sustainable economic development. Most of the institutions in the world are focused on support programs for the development of family businesses, trying to create sustainable economic development of the country(Senay Agcaa \& Abon Mozumdarb, 2008). Barriers that hinder the growth of small business have classified them into barriers: Financial, Management, Institutional and Market Capabilities (Doern, Rachel, 2011).

For more family business financing source are the main barrier in growing of business. Despite the great desire to boost business, families have barriers to finding financial resources. High funding costs push many businesses to rely on their own resources or to 
borrow small amounts allowed by banks limiting the possibility of growth in this way(Casson, 2005). While skills barriers are related to the lack of skills and experience of owners and employees. This barrier can also be called a barrier to qualified Human Resources. So, small and family businesses lack managerial and marketing skills(Jimmy Liewa \& Maria Vassalou, 2000). Those authors say that, small business do not invest in training of staff and managerial. According of them, staff training of business should be count as a company invest which without it growing of business would be imposible. Institutional barriers are regulated which must apply business during of their growth and development.

This rules include fomal and nonfomal barriers which regulate economic activity influencing in social environment, economic, political and technological inside of business operating (Scott Holmesa \& Sharyn Smitha, 1997). Those formal barriers refers laws and rules, and nonformal barriers include traditions and customs which are part of culture. In economic environment where formal barriers do not applied, increase impact of nonformal barrier. Market barriers have to do with a number of factors such as: market structure, the behavior of competition, competitive strategy, market requirements, export, etc. During external barriers in the market include changing of market and lack of demand, internal barriers can include finding of chances of market, choosing product or segment of wrong market (Chang- Soo Kim \& Lewis F. Davidson, 2004).

\section{Female Managers Alongside Male Managers}

Different researcher give different thought about female success in family business management. Despite the fact that women in different fields have achieved satisfactory levels of success compared to men, in business management we can not say we have got a good result.

Now a third of women are graduating in business and management schools, thus offering the possibility to have gender parity in the near future also at the boards of family businesses(Feminist, 2016).

(Portal, 2015)After their research, they conclude that men are more creative than women and tend to be promoted more quickly than women in many types of occupations.(Powell, 1993)he opposes somehow this idea, he says that women and men do not differentiate in their effectiveness as leaders, although some situations favor women and some other men. Generally, it don't exist any clear consencus from different students if effectivity of men and woman leaders differs in general or particular circumstances. In family businesses, the activity in which the family operates is of great importance in the managerial success of women.Some activities are used to seeing them as being guided by males such as: construction, etc., while others are more likely to be women.

So when discussing the leadership of some different activities, we can think of the two genders at the top of the business, solely on management skills. But some outdoor activities that are harder can not be thought of guided by feminine gender. Unilateral selective arguments imply that the superiority of women's competences should have diminished over time, so that the female gender is given sufficient opportunity to 
develop career in the management field(Gary N Powell, Anthony D. Butterfield, 1994). In developed countries, businesses are more women-oriented, where support systems are more developed by involving in enterprise access and information sources(OECD, 1998). The education of many women in the field of Management is bringing about changes in the field of family business, over time, family businesses are beginning to be led by those who have skills and tendencies for successful leadership and gender is not identified as a problem. Women are entering powerful fields such as: Agriculture, Construction, Production and in many other non-traditional areas that have more demand(Dan R. Dalton \& Catherine M. Dalton, 2010). Numerous studies regarding the type and size of the business showed that women tend to have lower business growth than men, and in terms of profit, it also results that women generate lower incomes than men. As an obstacle to the management and management of business for women is its nature, which is related to the care and maintenance of the family.

Authors ( Miri Lerner, Candida G. Brush, and Robert D. Hisrich, 1997) after a study, they pointed out that women run their businesses part-time in line with family responsibilities. Other studies show that women-run businesses are smaller and that they face more difficulties in responsiveness of small size and innovation. This significant division of managers by gender is most current most in developing countries where all processes, laws and regulations are still underway and their implementation is slower. In developed countries management by gender equality is emphasized in all institutions, whether state or private.(Mare, 2013), executive director at Vodafone Albania, says women are gaining strength that can bring a different perspective on decision making. "I really believe that the key to success is not on gender rather than on skills. We at Vodafone believe that gender equality is the key to a successful venture. "Teuta Vrushi, Finance Director at Digitalb says that women are characterized by imagination and intuition, determination, and willingness to move things up to the end. They are careful not to forget about any details and details that often take much value. Women accept mistakes and are encouraged to work and make more effort to change. According to studies by different psychologists, although women have the same managerial skills with men, this has not resulted in their progress on career paths.

\section{Impact of Manager's Age on Family Business Performance}

The Age of Managers to Result in Family Business Success should be equivalent to the successful business owner's managerial experience. The age and business experience is also important in the success and performance of the family business, based on the experience and the logic that a successful family business with over ten years of experience has gained more consumer confidence than a business new. The more mature the manager tends to have more dedication to the organization and future of the family business (Amran, 2011). The manager's age is of great importance for both the company's performance and the employment opportunities (Kim, 2007). He emphasizes that the more advanced the senior manager of his experience and his educational preparation also increases the propensity to self-employment. Different scholars have come up with different results regarding the manager's age and the success of family business. They point out that young managers find it easier to open and close 
business in case of failure in relation to more senior managers. We can say that family business for its performance and longevity always needs the advice of senior managers and the integration of young managers into family business. The reason is that new generations are much more easily adapting to technological change and global market development and are able to endanger risk more easily, but it is also advisable for old managers to take advantage of their experience in order to minimize the risk of harm to business and family. The manager's age can not be the determining determinant of family business success (Danielle Khalife \& Amani Chalouhi, 2013). Business management is also art and affinity that can be present either in new or old generations. We are witnessing many new businesses that have reached the top of the world market success that are managed by Young Managers, but at the same time we can not say the opposite even for Old Managers because we have many successful Managed Companies from older generations.

\section{Impact of Managerial Style in Performance of Family Business}

The hypothesis raised in this paper that creative management style enhances the success of family business compared to the classic style of management, corresponds to the class manager and leader. Authors (Stephen P. Robbins \& David De Cenzo, 2011), they oppose the opinions of many other authors who use the term leader as the manager's synonym. According to them managers and leaders are not the same. The difference lies in the fact that managers are appointed and have legitimate powers that allow them to reward and punish while leaders may be appointed or may appear within the group. Leaders can influence others to behave in ways that they can resort to actions dictated by formal authority. The manager and the leader also differ from the form of accomplishment of their work and goals. The Manager's task is to plan, organize and coordinate while the task of the leader is to inspire and motivate the business working staff(Alan Murray). Various studies have shown that many businesses, especially those in the family, have failed precisely because of the management, arrogance and excessive self-confidence of Managers who make all decisions about the family business without consulting with other members or experts field. The following table will show differences in the work of the classic and creative manager (Bennis, 1989).

Table 1. Differences between leader and classic manager

\begin{tabular}{|l|l|}
\hline CLASSIC MANAGER & CREATIVE MANAGER-LEADER \\
\hline The manager administers the current affairs & The leader deals with innovation \\
\hline The manager imitates & The leader is original \\
\hline $\begin{array}{l}\text { The manager is focused to have his/her business } \\
\text { in a good status }\end{array}$ & The leader focuses on business development \\
\hline The manager is focused in systems and structure & The leader focuses on people \\
\hline The manager rely in controll & The leader inspires confidence \\
\hline The manager is short-sighted & The leader has a vision for a long-term perspective \\
\hline The manager ask, How and When? & The leader asks what and why? \\
\hline The manager looks only in one way & The leader looks at the horizon \\
\hline The manager obeys & The leader looks at the horizon \\
\hline The manager does things right & The leader did the right thing \\
\hline
\end{tabular}

Source: Compiled by the author from the literature outlined 
Different scholars have given different thoughts and definitions about Management styles, including Dictatorial, Bureaucratic, Charismatic, Participative, Paternalist, Researchers, Consultants etc., who according to(Ibrahim Kuka, Justina Shiroka-Pula \& Besnik Krasniqi, 2006)are classified into three main categories:

$\checkmark$ Autocratic Style, where the leader centralizes authority, directs working methods, makes unilateral decisions, and limits worker participation.

$\checkmark$ The Democratic Style, where the leader includes decision makers, delegates authority, encourages participation in setting methods and work goals, and uses feedback as an opportunity for trained workers.

$\checkmark$ Laissez-faire style, where the leader gives freedom of workers to make decisions and to carry out their work in a way that they think most appropriate.

Authors(Stephen P. Robbins \& David De Cenzo, 2011), after some research into the effectiveness of three styles, emphasize that the Democratic leadership style can contribute both to the high quality and to the good quality of work.

Other authors point out that Management style should be determined depending on the situations in which the company is located. For a successful family business, the leader should have the ability to combine the leader's creative style advantages and the classleading edge of the manager.

\section{Management Gender in Family Business in Kosovo}

Numerous authors point out that the characteristics of managers and their skills are very important in the performance and business success. The questionnaire distributed to 379 Family Businesses provides us with enough information about the characteristics of the managers of these businesses as well as about their success and performance. From the research done in 379 businesses, $87 \%$ of them are managed by male managers, while the rest of $13 \%$ by female managers. This shows a kind of inequality regarding the management of companies by women compared to men.

Graphic 1. Manager's age

Source: Author (2016)

We can comment on this result in different ways, for example. as a lack of a female gender initiative to deal with a new business or to inherit Family Business, lack of courage to take responsibility for business management, which is the main source of family funding and its failure would have serious consequences for the well-being of the family, etc. However, I think there are other key factors in our society that hinder the 
management of family business by gender. Among the main factors is our mentality and primitivism, which makes us that female sex should only deal with housework, small family belief in their daughters as compared to boys, female attitude away from family business management, and so on.

\section{Impact of Managers and Business Characteristics on BF's Success}

Depending on the characteristics of Managers and business characteristics, it also affects the success and growth of family business performance. From previous research it is seen that some of these features have a greater impact on some of the few in the family business peoples. The table below shows results from 379 family businesses in our country, which provide a more illustrative response to the impact of managers and businesses on the performance of family business.

Table 2. Impact of managers and business characteristics on BF's success

\begin{tabular}{|l|c|c|c|c|c|}
\hline $\begin{array}{l}\text { The older the family business manager, the more successful } \\
\text { the business will be, the higher the profitability will be. }\end{array}$ & $\mathbf{3 6} \%$ & $19 \%$ & $29 \%$ & $8 \%$ & $6 \%$ \\
\hline $\begin{array}{l}\text { Male household business managers provide greater business } \\
\text { profitability and are more successful than female managers. }\end{array}$ & $8 \%$ & $11 \%$ & $24 \%$ & $21 \%$ & $\mathbf{3 3 \%}$ \\
\hline $\begin{array}{l}\text { Changing Management's style from classic to creative } \\
\text { management style helps boost business faster and in position } \\
\text { as a strong competitor in the market. }\end{array}$ & $1 \%$ & $4 \%$ & $11 \%$ & $32 \%$ & $\mathbf{4 9 \%}$ \\
\hline
\end{tabular}

Source: Author (2016)

From the table it can be seen that a large number of businesses around $36 \%$ of them did not agree "Not at all" with the statement that the older the family business manager, the more business success will be and the higher will be its profitability. Then the rest 19\% agreed "Little" with this assertion and 29\% "Somewhat" by showing a score that shows that most of our Family Business Managers do not think the age of Manager affects the success and performance of family business. Different results have the assertion that male household business managers provide greater business profitability and are more successful than female managers. 33\% of our family businesses agreed "Fully" with this statement, 21\% of them "Many", and 24\% "Somewhere". From these results we can see that in our country there is still the belief that gender has a great impact on family business performance and that male managers provide higher profits than female managers of family businesses. Regarding the management style impact on family business performance, 49\% of businesses have agreed "Fully" that changing management style from classic to creative management style helps boost business faster and faster as a strong competitor in the market. 32\% of businesses have agreed "Many" with this assertion that the style of management has an impact on the family business, and recommending businesses to change style from classic to creative management style.

\section{Conclusion and Recommendation}

Characteristics of Managers of Family Businesses, for which an answer is given, 
how influencing the performance of these businesses are gender, age and style of Management.

Management Gender- In the hypothesis that male managers have more success in Family Business Management than female managers, only a small number of Managers disagreed with this assertion. From this we can draw a conclusion that in the family business, in our country, the Gender of Managers has an impact on the performance and profitability of the business. It should be noted here that this is not about the higher skills of male managers compared to female managers but with the mentality of our country, which is often a barrier to equal development between the two sexes, thus also affecting the development of of the country.

Age of Manager - From the results obtained from the questionnaire, we see that the age of the manager does not have any major impact on increasing performance and business profitability. This is also confirmed by the fact that in every country of the world and in our country we have new Managers where their businesses are far more successful than other businesses of the same activity managed by older managers. But in this case is the other side of the medal because there are many successful businesses that are managed by older managers and are strong competitors in the market.

Determining the style of management- From this research, it is clear that the style of Management as a characteristic of Family Business Managers influences the growth of business performance and profitability. Management style varies with our businesses depending on the management skills that our business managers possess and their readiness to adapt to market changes. In conclusion, we can conclude that the continuous adaptation of the family business to the needs, demands and market conditions is one of the key factors of business success. In many of our businesses, we still apply the classic business management style, where managers have expressed their unwillingness to make changes to their management structure and step toward their business future preferring to continue managing as they are so far, without trying to research market changes or customer demands. Another conclusion that may enter the Management style that affects the long-term success of the business is the lack of a written plan for the business heir. From this research it is seen that most businesses do not have a written plan about the way of business inheritance to other family members.

\section{References}

Miri Lerner, Candida G. Brush, and Robert D. Hisrich. (1997). Israeli women entrepreneurs: An examination of factors affecting performance. Journal of Business Venturing , 315-334.

Alan Murray. (a.d.). What is the Difference Betëeen Management and Leadership? Gjetur 03 21, 2016, nga Guides.wsj.com: http://guides.wsj.com/management/developing-a-leadership-style/what-is-thedifference-between-management-and-leadership/

Amran, N. A. (2011). The effect of owner's gender and age to firm performance: a review on Malaysian public listed family businesses. Journal of global business and economics, 104-116.

Bennis, W. (1989). On Becoming a Leader. USA: Basic Books.

Casson, M. (2005). Entrepreneurship and the theory of the firm. Journal of Economic Behavior \& Organization, 327-348.

Chang- Soo Kim \& Lewis F. Davidson. (2004). The effects of IT expenditures on banks' business performance: using a balanced scorecard approach. Managerial Finance, 28-45.

Dan R. Dalton \& Catherine M. Dalton. (2010). Women and corporate boards of directors. Business Horizons, $257-268$. 
Danielle Khalife \& Amani Chalouhi. (2013). Gender and business performance . International Strategic Management Review , 1-10.

Doern, R. (2009). Investigating Barriers to SME Growth and Development in Transition Environments. International Small Business Journal , 275-305.

Doern, Rachel. (2011). Understanding how perceived barriers influence groëth intentions and behaviours: Accounts from small business oëner- managers in Russia. International Journal of Entrepreneurial Behavior \& Research , 488 - 514.

Feminist. (2016). Empowering Women in Business. Gjetur 03 16, 2016, nga www.feminist.org: http://www.feminist.org/research/business/ewb_myths.html

Gary N Powell, Anthony D. Butterfield. (1994). Investigating the "glass ceiling" phenomenon: An empirical study of actual promotions to top management. Academy of Management Journal, 68-86.

Ibrahim Kuka, Justina Shiroka-Pula \& Besnik Krasniqi. (2006). Menaxhmenti dhe Vendosja. Prishtine: NSHG Rilindja.

Jimmy Liewa \& Maria Vassalou. (2000). Can book-to-market, size and momentum be risk factors that predict economic growth? Journal of Financial Economics, 221-245.

Kim, G. (2007). The Analysis of Self-Employment Levels Over the Life-Cycle. Quarterly Review of economics and finance, 397-410.

Mare, D. (2013). Gratë në Sipërmarrje Sipermarrja dhe lidershipi në mjedisin shqipetar. Tirane: Deloitte.

OECD. (1998). Fostering Enterpreneurship: Organization for Economic Co - operation and Development. Paris.

Portal, A. C. (2015, 03 10). A jane meshkujt me kreative se femrat? Gjetur 03 17, 2016, nga acp.al: http://acp.al/posts/782/A-jane-meshkujt-me-kreative-se-femrat/?

Poëell, G. N. (1993). Women \& men in management. Newbury Park: Sage.

Scott Holmesa \& Sharyn Smitha. (1997). The Impact of Subsidised Business Advice Upon Aspects of NonFinancial Performance in Small Firms. Small Enterprise Research, 56-67.

Senay Agcaa \& Abon Mozumdarb. (2008). The impact of capital market imperfections on investment-cash flow sensitivity. Journal of Banking \& Finance, 207-216.

Stephen P. Robbins \& David De Cenzo. (2011). Bazat e Menaxbmentit Koncepte dhe aplikime themelore. Tirane: UET Press. 